\title{
SPATIAL AND LINEAR CORRELATIONS BETWEEN SOIL AND CORN(1)
}

\author{
Carlos Alessandro Chioderoli(2), Luiz Malcom Mano de Mello( ${ }^{(3)}$, Rafael Henrique de \\ Freitas Noronha ${ }^{(4)}$, Cristiano Magalhães Pariz ${ }^{(5)} \&$ Ronaldo Cintra Lima( ${ }^{(6)}$
}

\begin{abstract}
SUMMARY
The Technologies setting at Agricultural production system have the main characteristics the vertical productivity, reduced costs, soil physical, chemical and biological improvement to promote production sustainable growth. Thus, the study aimed to determine the variability and the linear and special correlations between the plant and soil attributes in order to select and indicate good representation of soil physical quality for forage productivity. In the growing season of 2006, on the Fazenda Bonança in Pereira Barreto (SP), the productivity of autumn corn forage (FDM) in an irrigated no-tillage system and the soil physical properties were analyzed. The purpose was to study the variability and the linear and spatial correlations between the plant and soil properties, to select an indicator of soil physical quality related to corn forage yield. A geostatistical grid was installed to collect soil and plant data, with 125 sampling points in an area of $2,500 \mathrm{~m}^{2}$. The results show that the studied properties did not vary randomly and that data variability was low to very high, with well-defined spatial patterns, ranging from 7.8 to $38.0 \mathrm{~m}$. On the other hand, the linear correlation between the plant and the soil properties was low and highly significant. The pairs forage dry matter versus microporosity and stem diameter versus bulk density were best correlated in the $0-0.10 \mathrm{~m}$ layer, while the other pairs - forage dry matter versus macro - and total porosity - were inversely correlated in the same layer. However, from the spatial point of view, there was a high inverse correlation between forage dry matter with microporosity, so that microporosity in the $0-0.10 \mathrm{~m}$ layer can be considered a good indicator of soil physical quality, with a view to corn forage yield.
\end{abstract}

Index terms: soil physical properties, soil management, geostatistics, no-tillage, forage crops.

(1) Received for publication in December 16, 2010 and approved in November 11, 2011.

(2) $\mathrm{PhD}$ Student in Agronomy (Soil Science), University of Agriculture Science and Veterinary, UNESP - Jaboticabal Campus, Department of Rural Engineering. Avenida Brasil 56, Centro, CEP 15385-000 Ilha Solteira (SP). E-mail: ca.chioderoli@uol.com.br

(3) Professor of the Department of Phytosanity, Soil and Rural Engeneering, UNESP - Ilha Solteira Campus. E-mail: malcolm@agr.feis.unesp.br

(4) Master's degree in Agronomy (Crop Production), UNESP - Jaboticabal Campus, Department of Rural Engineering. E-mail: rafnor86@yahoo.com.br

(5) PhD Student in Zootechny (Nutrition and Animal Production), UNESP - Butucatu Campus. E-mail: cmpariz@hotmail.com.br

(6) PhD in Agronomy (Vegetable Production System), UNESP - Ilha Solteira Campus. E-mail: rclima@agr.feis.unesp.br 


\title{
RESUMO: CORRELAÇÕES LINEARES E ESPACIAIS DO SOLO ASSOCIADO À CULTURA DO MILHO
}

\begin{abstract}
O conjunto de tecnologias aplicadas ao sistema de produção agrícola tem como características principais a verticalização da produtividade, diminuição de custos, melhoria nas características físicas, químicas e biológicas do solo para proporcionarem o crescimento sustentável do meio de produção. Desta forma, o trabalho teve como objetivo determinar a variabilidade e as correlações lineares e especiais entre os atributos da planta e do solo, visando selecionar um indicador da qualidade física do solo de boa representatividade para produção de forragem. No ano agrícola de 2006, na Fazenda Bonança, município de Pereira Barreto (SP), foram analisados a produtividade de forragem do milho outonal (FDM) em sistema plantio direto irrigado e os atributos físicos do solo, num Latossolo Vermelho distrófico. O objetivo foi estudar a variabilidade e as correlações lineares e espaciais entre os atributos da planta e os do solo, visando selecionar um indicador da qualidade física do solo de boa representatividade para a produtividade da forragem. Foi instalada a malha geoestatística, para coleta de dados do solo e planta, contendo 125 pontos amostrais, numa área de $2.500 \mathrm{~m}^{2}$. Os atributos estudados, além de não terem variado aleatoriamente, apresentaram variabilidade dos dados entre baixa e muito alta e seguiram padrões espaciais bem definidos, com alcances entre 7,8 e 38,0 m. Por outro lado, a correlação linear entre os atributos da planta com o do solo foi baixa e extremamente significativa. Os pares Massa Seca de forragem versus Microporosidade e Diâmetro do colmo versus Densidade do Solo foram melhor correlacionados na camada de 0-0.10m, enquanto os outros pares - Massa Seca de Forragem versus Macroporosidade - e Porosidade Total - apresentaram correlação inversa para a mesma camada. Entretanto, do ponto de vista espacial, houve uma alta correlação inversa entre Massa Seca de Forragem com Microporosidade, de modo que a microporosidade na camada de 0-0.10m pode ser considerada um bom indicador de qualidade física do solo, tendo em vista a produção de forragem de milho.
\end{abstract}

Termos de indexação: atributos físicos do solo, manejo do solo, geoestatística, semeadura direta, forragicultura.

\section{INTRODUCTION}

The soil compaction degree is expressed by the physical indicator of penetration resistance, and it is related positively with bulk density of soil, but negatively with macroporosity. High compaction degree affects the development of the root system (Bergamin et al., 2010).

According to Foloni et al. (2003), physical barriers in the subsoil alter the distribution of the root system of maize plants along the soil profile, however, the total root yield does not decrease. The authors further stated that a compacted soil layer with penetration resistance of $1.4 \mathrm{MPa}$ prevents maize roots from penetrating this layer and extending into the deeper ones.

Bulk density is closely related with other properties, as shown in a large number of studies indicating that increasing density causes reductions in total porosity, macroporosity, hydraulic conductivity, ion absorption, as well as increased microporosity and soil resistance to mechanical penetration. This general scenario results in decreased agricultural productivity (Secco et al., 2005; Mello Filho et al., 2006; Santos et al., 2006).

Soil compaction causes maize yield losses because of the physical changes in the root environment
(Debiasi et al., 2010). Also, the pore arrangement and size affect soil water retention, water availability to plants due to lower porosity and aeration, as well as soil penetration resistance (Cavalieri et al., 2006), limiting the soil depth and volume explored by the roots.

Assis \& Lanças (2004) verified a decrease in soil bulk density after 12 years, related to the time of adoption of no-tillage system. They observed a diversity of responses to the same management system according to the different soil, plant, climate and other characteristics. The highest values of soil bulk density in the first years of the no-tillage system were caused by the absence of soil tillage, but over the years the undesirable effect of this compaction disappears, as the no-till system is established properly.

According to Mercante et al. (2003) and Secco et al. (2005), total porosity is strongly related with soil compaction and penetration resistance, which tend to increase with the reduction of pore space. The density and pore space can be used as indicators of soil quality according to the soil management. A continuous assessment over time of these soil physical properties, can indicate how efficient these management systems are in terms of structural stability (Secco et al., 2005). 
Geostatistics has been increasing used in the evaluation of the spatial variability of agricultural parameters of interest, allowing the interpretation of results based on the structure of their natural variability, considering the existence of spatial dependence within the sample space. Thus, currently spatial variability research is being conducted on a large scale, especially to study the properties of the ratio soil mass / volume and plant productivity (Freddi et al., 2006; Mello Filho et al., 2006; Santos et al., 2006).

Spatial variability can be represented by maps, constructed from the estimates of the variable studied by the kriging technique (Carvalho et al., 2003). The correlation coefficient (r) between these values reflects the efficiency of adjustment, given by the technique of sum of squared deviations, representing the linear regression equation in question. A perfect fit would have a regression coefficient equal to one and the line of best fit would coincide with the perfect model, i.e., having a linear coefficient equal to 0.00 and an angle equal to one.

The objective was to study the variability and linear and spatial correlations between the plant and soil properties in order to select an indicator of soil physical quality that is also related to forage yield.

\section{MATERIAL AND METHODS}

The experiment was conducted in a pivotirrigated area in an integrated crop livestocksystem. The area had been used for six years as irrigated pasture with Brachiaria brizantha cv Marandu, in an intensive rotation systems, in Pereira Barreto, Sao Paulo State, Brazil (2040' 12" latitude S; $51^{\circ} 01^{\prime} 50^{\prime \prime}$ longitude $\mathrm{W}$ ). The average annual precipitation was $1300 \mathrm{~mm}$ and temperature $24.1^{\circ} \mathrm{C}$. The local climatic was classified as Aw, according to Köppen, characterized as humid tropical with rainy summers and dry winters. The soil was classified as dystrophic red latosol (Typic Haplustox), sandy clay loam, allic, no compacted, strongly acidic, according to Embrapa (2006).

The single-cross maize hybrid P30F80 was sown in no-tillage on 10 February, 2005, at a spacing of $0.85 \mathrm{~m}$ and density of 5.5 seeds per meter, on the pasture desiccated 20 days before. Fertilization consisted of $320 \mathrm{~kg} \mathrm{ha}^{-1}$ of NPK fertilizer (08-28-16) and of fertirrigation with two applications of $106 \mathrm{~kg}$ urea, 16 and 38 days after maize sowing (DAS) and an application of potassium chloride of $150 \mathrm{~kg} \mathrm{ha}^{-1}$, 23 DAS.

The experimental grid consisted of a total of 125 sampling points, distributed over an area of $2500 \mathrm{~m}^{2}$ $(50 \times 50 \mathrm{~m})$, with an average slope of $0.025 \mathrm{~m} \mathrm{~m}^{-1}$, and sample points spaced $5 \mathrm{~m}$ apart and in the finer grid $1 \mathrm{~m}$, established to detect ranges of spatial dependence for smaller spacing conditions than of the large grid.

In this way, the evaluation areas used to collect soil and plant data were defined: a) large grid, width $3.40 \mathrm{~m}$ (4 plant rows) by $3.40 \mathrm{~m}$ in the direction of the row, covering an area of $11.56 \mathrm{~m}^{2}$, and b) grid refinement on the $x$ axis, with $2.55 \mathrm{~m}$ (3 rows) by $1.00 \mathrm{~m}$, evaluation area of $2.55 \mathrm{~m}^{2}$, and on the $y$ axis, with $1.70 \mathrm{~m}$ (2 rows) by $1.50 \mathrm{~m}$, evaluation area of $2.55 \mathrm{~m}^{2}$.

The soil physical characteristics assessed per sampling point were bulk density (BD), macroporosity (MA), microporosity (MI) and total porosity (TP), sampled from the layers $0.00-0.10,0.10-0.20$ and $0.20-0.30 \mathrm{~m}, 120$ days after seeding, analyzed by the volumetric ring method (Embrapa, 1997), identified as BD1, MA1, MI1 and TP1 in the layer $0.00-0.10 \mathrm{~m}$; BD2, MA2, MI2, and TP2 in the layer 0.10-0.20 m; and BD3, MA3, MI3, and TP3 in the layer $0.20-0.30 \mathrm{~m}$, were analyzed at a laboratory of the Faculdade de Engenharia de Ilha Solteira (FEIS/UNESP).

The forage dry matter (FDM) was assessed 110 DAS individually for each sample point, by oven-drying at $65^{\circ} \mathrm{C}$ to constant weight. By classical descriptive analysis, the average, median, minimum and maximum standard deviation, coefficient of variation, kurtosis, skewness, and analysis of frequency distribution were calculated and normality tested. Outliers were replaced by the average value of the surrounding grid points.

The highest simple linear correlations were adopted that could present the cross-semivariogram and therefore co-kriging performance. Crossvalidation is a tool to evaluate alternative models of simple and cross-semivariograms that perform kriging and co-kriging, respectively. So, to obtain the optimum number of neighbors, kriging and cokriging maps were obtained by interpolation, for the analysis of spatial dependence and interdependence between properties.

Multiple linear regression was used for the soil layers studied by means of the plant dependent variable (FDM) and of the soil independent variables (soil properties), in order to select the best relations between cause and effect, assessed by the determination coefficient, using the extra step of SAS.

\section{RESULTS}

Descriptive statistics showed that for corn forage yield and soil properties (Table 1), the variability for FDM, and MA2c and MA3c was average, and high for MA1, unlike of the other properties, with 
Table 1. Descriptive analysis of some properties of the original corn forage productivity and soil physical properties of a Dystrophic Red Latosol

\begin{tabular}{|c|c|c|c|c|c|c|c|c|c|c|}
\hline \multirow{3}{*}{ Property $^{(1)}$} & \multicolumn{10}{|c|}{ Descriptive statistics } \\
\hline & \multirow{2}{*}{ Average } & \multirow{2}{*}{ Median } & \multicolumn{2}{|c|}{ Value } & \multirow{2}{*}{ Standard deviation } & \multicolumn{3}{|c|}{ Coefficients } & \multicolumn{2}{|c|}{ Probability test ${ }^{2}$} \\
\hline & & & Min. & Max. & & CV (\%) & $C k$ & Cs & $\operatorname{Pr}<w$ & FD \\
\hline \multicolumn{11}{|c|}{ Plant Properties } \\
\hline FDM & 14892 & 15029 & 8949 & 23198 & 2415 & 16.3 & 0.644 & 0.008 & 0.343 & $\mathrm{NO}$ \\
\hline $\mathrm{STD}(\mathrm{cm})$ & 2.49 & 2.50 & 2.13 & 2.81 & 0.126 & 5.1 & 0.320 & -0.346 & 0.330 & $\mathrm{NO}$ \\
\hline \multicolumn{11}{|c|}{ Macroporosity $\left(\mathrm{m}^{3} \mathrm{~m}^{-3}\right)$} \\
\hline MA1 & 0.066 & 0.065 & 0.023 & 0.129 & 0.025 & 38.3 & -0.505 & 0.409 & 0.005 & IN \\
\hline MA2 $\mathrm{c}^{(3)}$ & 0.057 & 0.058 & 0.022 & 0.126 & 0.169 & 22.4 & -0.158 & -0.058 & 0.357 & $\mathrm{LN}$ \\
\hline MA3c $c^{(3)}$ & 0.061 & 0.062 & 0.023 & 0.142 & 0.177 & 22.6 & -0.417 & -0.283 & 0.089 & $\mathrm{LN}$ \\
\hline \multicolumn{11}{|c|}{ Microporosity $\left(\mathrm{m}^{3} \mathrm{~m}^{-3}\right)$} \\
\hline MI1 & 0.235 & 0.236 & 0.174 & 0.306 & 0.022 & 9.5 & 0.633 & 0.021 & 0.280 & $\mathrm{NO}$ \\
\hline MI2 & 0.232 & 0.234 & 0.180 & 0.300 & 0.018 & 8.0 & 1.059 & 0.008 & 0.115 & $\mathrm{NO}$ \\
\hline MI3 & 0.242 & 0.241 & 0.175 & 0.298 & 0.022 & 9.1 & 0.847 & -0.366 & 0.098 & NO \\
\hline \multicolumn{11}{|c|}{ Total Porosity $\left(\mathrm{m}^{3} \mathrm{~m}^{-3}\right)$} \\
\hline $\mathrm{TP} 1 \mathrm{~b}^{(3)}$ & 0.300 & 0.299 & 0.222 & 0.397 & 0.049 & 10.2 & -0.106 & 0.369 & 0.064 & $\mathrm{LN}$ \\
\hline TP2 & 0.289 & 0.289 & 0.234 & 0.348 & 0.021 & 7.3 & 1.028 & 0.505 & 0.003 & IN \\
\hline TP3b ${ }^{(3)}$ & 0.306 & 0.302 & 0.230 & 0.402 & 0.045 & 9.2 & 0.263 & 0.213 & 0.224 & $\mathrm{LN}$ \\
\hline \multicolumn{11}{|c|}{ Bulk Density $\left(\mathrm{kg} \mathrm{dm}^{-3}\right)$} \\
\hline BD1 & 1.64 & 1.65 & 1.41 & 1.82 & 0.073 & 4.4 & 0.903 & -0.392 & 0.079 & $\mathrm{NO}$ \\
\hline BD2 & 1.68 & 1.68 & 1.49 & 1.88 & 0.070 & 4.1 & 1.021 & -0.071 & 0.069 & NO \\
\hline BD3 & 1.67 & 1.66 & 1.43 & 1.85 & 0.078 & 4.7 & 0.698 & 0.050 & 0.084 & NO \\
\hline
\end{tabular}

(1) FDM: forage dry matter, STD: stem diameter, MA, MI, TP and BD are, respectively, macroporosity, microporosity, total porosity and bulk density in the soil layers $1(0-0.10 \mathrm{~m}), 2(0.10-0.20 \mathrm{~m})$ and $3(0.20-0.30 \mathrm{~m})$. ${ }^{(2)} \mathrm{FD}$ : frequency distribution, being NO, $\mathrm{LN}$, and IN, respectively, normal, lognormal, and indefinite. $\left.{ }^{(3)} 1\right)$ the values of the properties followed by the letters $\mathrm{b}$ and $\mathrm{c}$ were represented by decimal logarithms, respectively, divided by 10 and 100, and 2) average, median, minimum and maximum values of $\mathrm{x} *$ were retro-transformed by $\mathrm{x} *=10^{\log x}$. Ck: kurtosis, Cs: asymmetry.

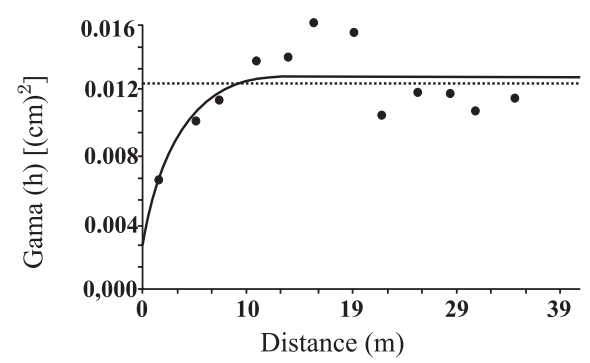

(1)

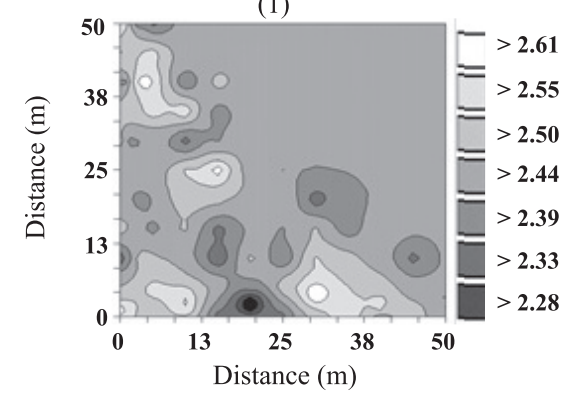

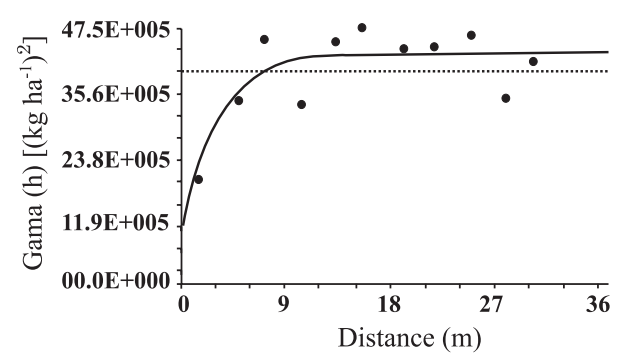

(2)

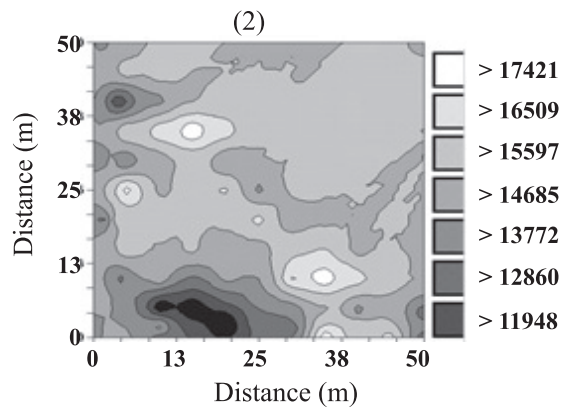

Figure 1. Adjusted semivariogram and kriging maps of the properties of corn forage productivity: (1) FDM and (2) STD. 


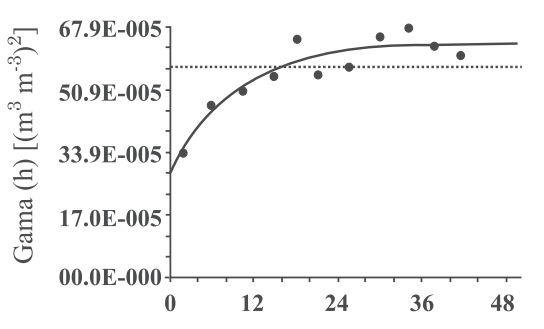

(1)

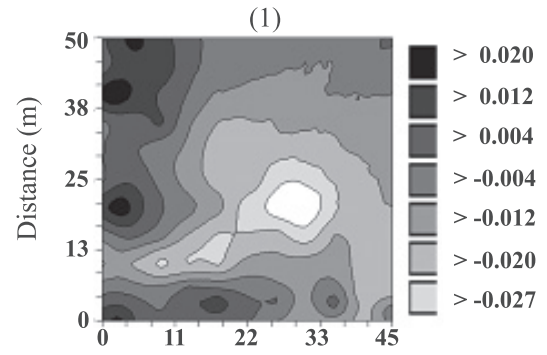

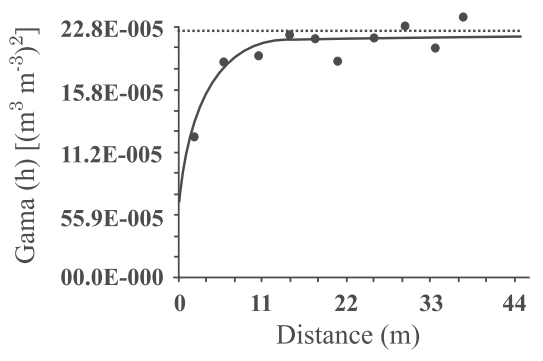

(2)

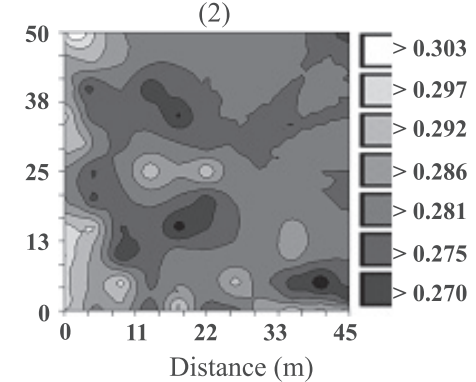

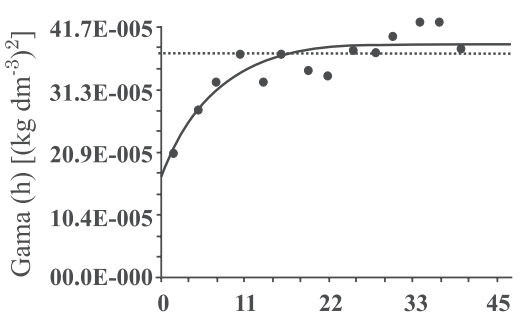

(3)

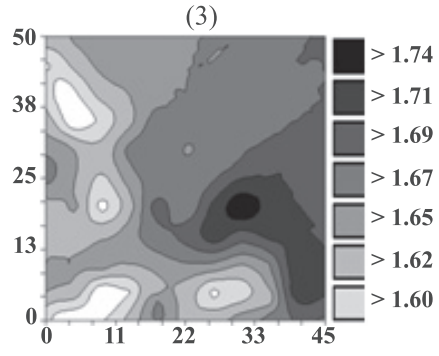

Figure 2. Adjusted semivariogram and kriging maps of some properties in different layers: 1) Microporosity in layer 0-0.10 m (\#MI1), 2) Total Porosity in layer 0.10-0.20 m (TP2), 3) Bulk Density in layer 0-0.10 m (BD1).

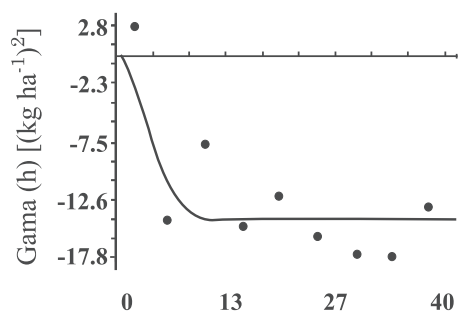

(1)

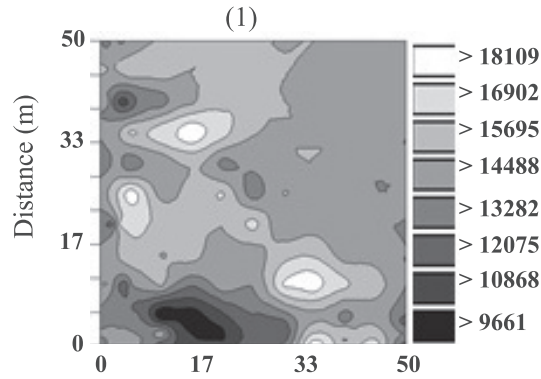

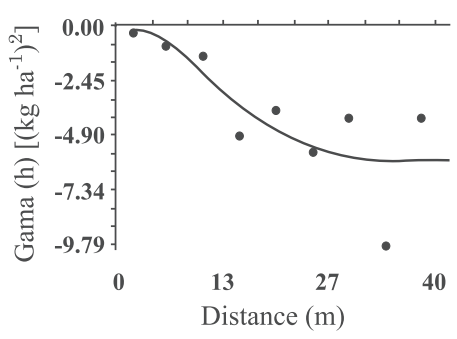

(2)

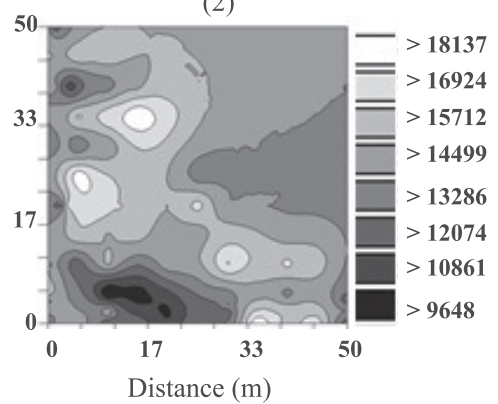

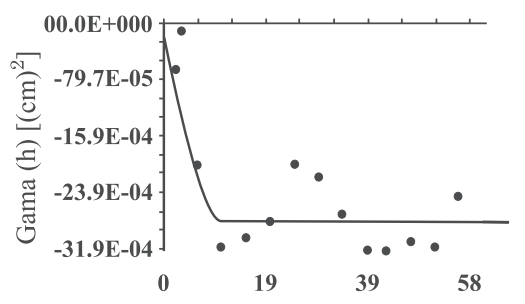

(3)

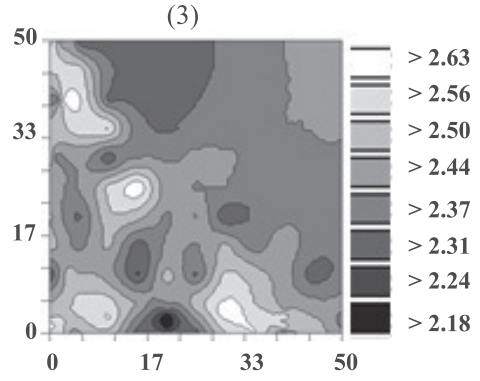

Figure 3. Cross-semivariograms and kriging maps for some properties of corn forage productivity and soil physical properties of a Dystrophic Red Latosol. 1) Forage dry matter vs microporosity in layer 0-0.10 m, 2) Forage dry matter $v$ s total porosity in layer 0.10-0.20 m, 3) Stem diameter vs bulk density in layer 0-0.10 m.

low variability. For soil porosity, the lognormal frequency distribution was indefinite for TP1b, TP3b and TP2. On the other hand, the distribution of bulk density was normal.

The correlations between the plant and soil properties were high, a fact justified by the high number of observations $(n=125)$. Significance was observed for the pairs FDM x MA1 $(r=-0.160 * *)$; FDM x MA3c $\left(r=0.129^{*}\right)$; FDM x MI1 $\left(r=-0.147^{* *}\right)$; and FDM x TP1b $\left(r=-0.225^{* *}\right)$.
The geostatistical analysis of co-kriging (Figure 3) indicated that the cross-semivariograms for the properties FDM = $\mathrm{f}(\# \mathrm{MI} 1), \mathrm{FDM}=\mathrm{f}(\mathrm{TP} 2)$ and STD $=\mathrm{f}(\mathrm{BD} 1)$, respectively, had coefficients of spatial determination of $0.725 ; 0.639$ and 0.697 . Also, Gaussian setting was identified for the properties $\mathrm{FDM}=\mathrm{f}(\# \mathrm{MI} 1)$ and $\mathrm{FDM}=\mathrm{f}$ (TP2), and spherical for $\mathrm{STD}=\mathrm{f}(\mathrm{BD} 1)$, with ranges between $8.9 \mathrm{~m} \mathrm{FDM}=$ $\mathrm{f}$ (\#MI1) and $29.0 \mathrm{~m} \mathrm{FDM} \mathrm{=} \mathrm{f} \mathrm{(TP2),} \mathrm{as} \mathrm{well} \mathrm{as} \mathrm{a} \mathrm{high}$ spatial dependence (SPD) for all (Table 2). 
Table 2. Parameters of the semivariograms adjusted to some properties of corn forage yield and soil physical properties of a Dystrophic Red Latosol

\begin{tabular}{|c|c|c|c|c|c|c|c|c|}
\hline \multirow{2}{*}{ Property $^{(1)}$} & \multicolumn{8}{|c|}{ Parameters } \\
\hline & Model $^{(2)}$ & $\begin{array}{c}\text { Nugget effect } \\
\left(C_{0}\right)\end{array}$ & $\begin{array}{l}\text { Threshold } \\
\left(C_{0}+C\right)\end{array}$ & $\begin{array}{l}\text { Range } \\
(\mathrm{m})\left(\mathrm{A}_{0}\right)\end{array}$ & $\mathbf{r}^{2}$ & $\mathbf{S S R}^{(3)}$ & $\begin{array}{l}\text { SPD } \\
(\%)(4)\end{array}$ & $\begin{array}{l}\text { Class of spatial } \\
\text { dependence }\end{array}$ \\
\hline \multicolumn{9}{|c|}{$\gamma(\mathrm{h})$ simple properties of the plant } \\
\hline FDM $\left(\mathrm{kg} \mathrm{ha}^{-1}\right)$ & $\operatorname{Exp}$ & $1.000 .10^{6}$ & $4.296 .10^{6}$ & 9.7 & 0.680 & $2.140 .10^{12}$ & 76.7 & high \\
\hline $\mathrm{STD}(\mathrm{cm})$ & $\operatorname{Exp}$ & $2.020 .10^{-3}$ & $1.284 .10^{-2}$ & 8.6 & 0.524 & $3.515 .10^{-5}$ & 84.3 & high \\
\hline \multicolumn{9}{|c|}{$\gamma(\mathrm{h})$ simple properties of the soil } \\
\hline $\operatorname{MA} 1\left(\mathrm{~m}^{3} \mathrm{~m}^{-3}\right)$ & Pne & $6.290 .10^{-4}$ & $6.290 .10^{-4}$ & - & - & - & - & - \\
\hline MA2c $\left(\mathrm{m}^{3} \mathrm{~m}^{-3}\right)$ & Sph & $9.650 .10^{-3}$ & $2.150 .10^{-2}$ & 38.0 & 0.835 & $4.489 .10^{-5}$ & 55.1 & moderate \\
\hline $\operatorname{MA3c}\left(\mathrm{m}^{3} \mathrm{~m}^{-3}\right)$ & Pne & $3.246 .10^{-2}$ & $3.246 .10^{-2}$ & - & - & - & - & - \\
\hline \#MI1 $\left(\mathrm{m}^{3} \mathrm{~m}^{-3}\right)$ & $\operatorname{Exp}$ & $2.740 .10^{-4}$ & $6.350 .10^{-4}$ & 26.9 & 0.857 & $1.363 .10^{-8}$ & 56.9 & moderate \\
\hline \#MI2 $\left(\mathrm{m}^{3} \mathrm{~m}^{-3}\right)$ & $\mathrm{Sph}$ & $4.800 .10^{-5}$ & $1.730 .10^{-4}$ & 7.8 & 0.692 & $3.043 .10^{-9}$ & 72.3 & moderate \\
\hline \#MI3 $\left(\mathrm{m}^{3} \mathrm{~m}^{-3}\right)$ & Pne & $4.870 .10^{-4}$ & $4.870 .10^{-4}$ & - & - & - & - & - \\
\hline \#TP1b $\left(\mathrm{m}^{3} \mathrm{~m}^{-3}\right)$ & Sph & $2.100 .10^{-4}$ & $1.372 .10^{-2}$ & 16.1 & 0.942 & $9.946 .10^{-6}$ & 98.5 & high \\
\hline $\mathrm{TP} 2\left(\mathrm{~m}^{3} \mathrm{~m}^{-3}\right)$ & Exp & $5.900 .10^{-5}$ & $2.080 .10^{-4}$ & 10.3 & 0.871 & $9.750 .10^{-10}$ & 71.6 & moderate \\
\hline TP3b $\left(\mathrm{m}^{3} \mathrm{~m}^{-3}\right)$ & Exp & $6.850 .10^{-4}$ & $1.380 .10^{-3}$ & 19.0 & 0.923 & $2.025 .10^{-8}$ & 50.4 & moderate \\
\hline $\mathrm{BD} 1\left(\mathrm{~kg} \mathrm{dm}^{-3}\right)$ & Exp & $1.550 .10^{-3}$ & $3.820 .10^{-3}$ & 20.6 & 0.809 & $8.198 .10^{-7}$ & 59.4 & moderate \\
\hline BD2 $\left(\mathrm{kg} \mathrm{dm}^{-3}\right)$ & Sph & $8.480 .10^{-4}$ & $2.706 .10^{-3}$ & 9.0 & 0.878 & $2.422 .10^{-7}$ & 68.7 & moderate \\
\hline BD3 $\left(\mathrm{kg} \mathrm{dm}^{-3}\right)$ & Exp & $1.210 .10^{-3}$ & $5.110 .10^{-3}$ & 10.4 & 0.797 & $1.089 .10^{-6}$ & 76.3 & high \\
\hline \multicolumn{9}{|c|}{$\gamma(\mathrm{h})$ simple plant and soil properties } \\
\hline $\mathrm{FDM}=\mathrm{f}(\# \mathrm{MI} 1)\left[\mathrm{kg} \mathrm{ha}^{-1}\right]$ & gau & $-1.000 .10^{-2}$ & $-1.445 .10^{1}$ & 8.9 & 0.725 & $1.080 .10^{2}$ & 99.9 & high \\
\hline $\mathrm{FDM}=\mathrm{f}(\mathrm{TP} 2)\left[\mathrm{kg} \mathrm{ha}^{-1}\right]$ & gau & $-1.000 .10^{-2}$ & -6.180 & 29.0 & 0.639 & $2.450 .10^{1}$ & 99.8 & high \\
\hline $\mathrm{STD}=\mathrm{f}(\mathrm{BD} 1)\left[\mathrm{kg} \mathrm{ha}^{-1}\right]$ & $\mathrm{sph}$ & $-1.000 .10^{-6}$ & $-2.792 .10^{3}$ & 11.5 & 0.697 & $1.981 .10^{-6}$ & 99.9 & high \\
\hline
\end{tabular}

(1) FDM: forage dry matter, STD: stem diameter, MA, MI, TP and BD are respectively the macroporosity, microporosity, total porosity and bulk density in the soil layers $1(0-0.10 \mathrm{~m}), 2(0.10-0.20 \mathrm{~m})$ and $3(0.20-0.30 \mathrm{~m}) .{ }^{(2)} \mathrm{sph}$ : spherical; exp: exponential, pne: pure nugget effect. ${ }^{(3)}$ SSR: sum of squared residuals. ${ }^{(4)}$ SPD: spatial dependence.

Table 3. Parameters of cross-validations for some properties of corn forage yield and soil physical properties of a Dystrophic Red Latosol

\begin{tabular}{|c|c|c|c|c|c|}
\hline \multirow{2}{*}{ Property $^{(1)}$} & \multicolumn{2}{|c|}{ Standard error } & \multirow{2}{*}{ Correlation coefficient (r) } & \multicolumn{2}{|c|}{$\mathrm{OV}=\mathbf{a}+\mathbf{b} \cdot \mathbf{E V}^{(2)}$} \\
\hline & obs. & est. & & a & $\mathbf{b}$ \\
\hline \multicolumn{6}{|c|}{$\gamma(\mathrm{h})$ simple plant properties } \\
\hline FDM $\left(\mathrm{kg} \mathrm{ha}^{-1}\right)$ & 0.158 & 1726 & 0.502 & $8.395 .10^{2}$ & 0.947 \\
\hline $\mathrm{STD}(\mathrm{cm})$ & 0.145 & 0.095 & 0.516 & $2.595 .10^{-1}$ & 0.896 \\
\hline \multicolumn{6}{|c|}{$\gamma(\mathrm{h})$ simple soil properties } \\
\hline MA2c $\left(\mathrm{m}^{3} \mathrm{~m}^{-3}\right)$ & 0.143 & 0.117 & 0.535 & $4.210 .10^{-2}$ & 0.941 \\
\hline$\# \mathrm{MI} 1\left(\mathrm{~m}^{3} \mathrm{~m}^{-3}\right)$ & 0.154 & 0.021 & 0.491 & $-1.000 .10^{-4}$ & 0.930 \\
\hline \#MI2 $\left(\mathrm{m}^{3} \mathrm{~m}^{-3}\right)$ & 0.184 & 0.012 & 0.383 & $3.000 .10^{-4}$ & 0.801 \\
\hline \#TP1b $\left(\mathrm{m}^{3} \mathrm{~m}^{-3}\right)$ & 0.083 & 0.077 & 0.696 & $6.200 .10^{-2}$ & 0.872 \\
\hline TP2 $\left(\mathrm{m}^{3} \mathrm{~m}^{-3}\right)$ & 0.183 & 0.013 & 0.455 & $1.260 .10^{-2}$ & 0.956 \\
\hline TP3b $\left(\mathrm{m}^{3} \mathrm{~m}^{-3}\right)$ & 0.206 & 0.033 & 0.338 & $1.140 .10^{-1}$ & 0.765 \\
\hline $\mathrm{BD} 1\left(\mathrm{~kg} \mathrm{dm}^{-3}\right)$ & 0.154 & 0.051 & 0.525 & $6.200 .10^{-3}$ & 0.997 \\
\hline BD2 $\left(\mathrm{kg} \mathrm{dm}^{-3}\right)$ & 0.219 & 0.046 & 0.400 & $-3.600 .10^{-3}$ & 1.002 \\
\hline BD3 $\left(\mathrm{kg} \mathrm{dm}^{-3}\right)$ & 0.175 & 0.062 & 0.410 & $2.730 .10^{-1}$ & 0.836 \\
\hline \multicolumn{6}{|c|}{$\gamma(\mathrm{h}))$ simple plant and soil properties } \\
\hline $\mathrm{FDM}=\mathrm{f}(\# \mathrm{MI} 1)\left[\mathrm{kg} \mathrm{ha}^{-1}\right]$ & 0.125 & 1847 & 0.424 & $6.282 .10^{3}$ & 0.581 \\
\hline $\mathrm{FDM}=\mathrm{f}(\mathrm{TP} 2)\left[\mathrm{kg} \mathrm{ha}^{-1}\right]$ & 1.131 & 1920 & 0.381 & $7.307 .10^{3}$ & 0.507 \\
\hline $\mathrm{STD}=\mathrm{f}(\mathrm{BD} 1)\left[\mathrm{kg} \mathrm{ha}^{-1}\right]$ & 0.116 & 0.102 & 0.430 & 1.140 & 0.543 \\
\hline
\end{tabular}

(1) FDM: forage dry matter, STD: stem diameter, MA, MI, TP and BD are respectively the macroporosity, microporosity, total porosity and bulk density in the soil layers $1(0-0.10 \mathrm{~m}), 2(0.10-0.20 \mathrm{~m})$ and $3(0.20-0.30 \mathrm{~m}) .{ }^{(2)} \mathrm{OV}$ : observed value, and EV: estimated value. 


\section{DISCUSSION}

The variability of a property can be classified according to the magnitude of the variation coefficient (Freddi et al., 2006). In this study, the variability of FDM, MA2c and the MA3c was average, of MA1 it was high and for the other variables low (Table 1), in agreement with Carvalho et al. (2002, 2003), Johann et al. (2004), Souza et al. (2004a, b) and Grego \& Vieira (2005). Soil variability is the product of interaction between the factors and processes of its formation, soil management and tilling. These factors are also determinant for the heterogeneity, observed in the MA1 results, where the minimum tillage performed by the no-tillage seeder resulted in the highest coefficients of variation observed in the first layer.

The high rooting in the soil surface from previous crops can result in a very porous soil structure and, consequently, increase forage yields in the following growing seasons, corroborating Freddi et al. (2008), who stated that yields are correlated with an adequate development of the aboveground plant parts, at lower soil density, providing higher root dry matter production. According to Souza Neto et al. (2008) and Araújo et al. (2010) reported that the soil physical properties and maize productivity in notillage systems promoted higher aggregate stability and soil bulk density in the surface layer, without changing the content of water available to plants.

The frequency distribution of macroporosity was indefinite in the surface layer (MA1). In the subsurface (MA2, MA3), lognormal distribution was observed, with increased soil compaction in the second and third layers, in agreement with Souza et al. (2001), Carvalho et al. (2002) and Melo Filho et al. (2006). In conservation tillage systems, the action of roots, macro and micro-organisms promoted a good macropore volume, and the mulch of crop residues on the surface retained soil moisture (Lima et al., 2006). Compression pressure applied to the soil can induce pore space reduction, especially of macropores (Dexter et al., 2007), whereas the micropores under pressure may be full of water and, because of the low hydraulic conductivity and incompressibility of water, may be able to resist stress better over short time intervals than air-filled macropores (Kutýleka et al., 2006; Silva et al., 2009).

Soil porosity (Table 1) showed lognormal frequency distribution for TP1b and TP3b, and for TP2, an indefinite distribution was observed, with average values of $0.300 \mathrm{~m}^{3} \mathrm{~m}^{-3}$ (TP1), $0.289 \mathrm{~m}^{3} \mathrm{~m}^{-3}$ (TP2) and $0.306 \mathrm{~m}^{3} \mathrm{~m}^{-3}$ (TP3). Thus, the distribution of density values was not logical as they did not increase in the deeper layers, in disagreement with Souza et al. (2001), Carvalho et al. (2002) and Melo Filho et al.
(2006). Therefore, this fact may have contributed to a reduction of FDM, which did not reach, despite the use of irrigation, the full expression of the yield capacity of the maize hybrid P30F80.

For soil bulk density (Table 1), the frequency distribution was normal for $\mathrm{BD} 1, \mathrm{BD} 2$ and $\mathrm{BD} 3$, as also observed by Johann et al. (2004), Souza et al. (2004a), and Grego \& Vieira (2005). The average values were $1.64 \mathrm{~kg} \mathrm{dm}^{-3}$ (BD1), $1.68 \mathrm{~kg} \mathrm{dm}^{-3}$ (BD2) and $1.67 \mathrm{~kg} \mathrm{dm}^{-3}$ (BD3), following a positive linear trend in relation to the increase in soil depth, corroborating Souza et al. (2001) and Carvalho et al. (2002), who reported an increased density in deeper layers, due to the reduced content of organic matter, and in disagreement with Grego \& Vieira (2005) and Melo Filho et al. (2006), who found a decreasing gradient.

The first pair (FDM x MA1) indicated an inverse function of cause and effect, i.e., the lower the macroporosity, in the $0.00-0.10 \mathrm{~m}$ layer, the greater is FDM. The second pair (FDM x MA3c) showed a positive correlation between cause and effect, indicating the increase of FDM with increasing macroporosity in the $0.20-0.30 \mathrm{~m}$ layer. This corroborated Pereira et al. (2010) who evaluated the physical quality of a Dystrophic Red Latosol under cover crops in pre-season maize, in conventional and no-tillage systems, and found higher values of total porosity in no-tillage than conventional tillage soils (Table 2).

In the third pair (FDM x MI1), due to negative correlation, ie, with lower microporosity in the surface layer, FDM increased. Scientifically speaking, the fact that occurred in the third pair was consistent, because when soil macroporosity increases, microporosity decreases. In the fourth pair (FDM x TP1b), a negative correlation between cause and effect was observed, indicating the increase of FDM with the lowest total porosity in the 0.00-0.010 m layer. However, for the first and fourth pair, this fact could not be confirmed, since the negative correlation of FDM x MA1 and FDM $x$ TP1b was precisely the opposite of what would be consistent.

Thus, FDM in relation to TP1b and STD in relation to $\mathrm{BD} 1$ can be estimated by the following simple linear regression equations:

$$
\begin{gathered}
\text { FDM }=1.084 .104 \times \text { TP1b, with } \mathrm{r}=0.242, \mathrm{p}<0.01 \\
\mathrm{STD}=3.360-5.299 .10^{-1 * *} . \mathrm{BD} 1, \\
\text { with } \mathrm{r}=0.306, \mathrm{p}<0.01
\end{gathered}
$$

Of the soil properties, the best-correlated pair was MA1 x TP1b, with the equation: 


$$
\begin{gathered}
\text { MA1 = }-1.081 .10^{-1}+3.648 .10^{-1 * *} . \text { TP1b } \\
\text { with } \mathrm{r}=0.706, \mathrm{p}<0.01
\end{gathered}
$$

The geostatistical analysis of kriging (Table 2) showed excellent plant and soil semivariograms (Figures 1 and 2). The best-fitting was adjusted to \#TP1b, with a spatial determination coefficient of 0.942 , and 0.680 for FDM. On the other hand, the studied properties showed spatial dependence, except for MA1, \# MA3c and MI3.

Thus, in this study (Table 2), it was found that $76.7 \%$ of the total FDM variation was explained by spatial dependence. On the other hand, the nugget effect attributed to random errors was $23.3 \%$. For the studied properties, the adjusted models were exponential (FDM, STD, \#MI1, TP2, TP3b, BD1 and BD3), spherical (MA2c, \#MI2, \#TPIb and BD2) and the pure nugget effect (MA1, MA3c and \#MI3).

With regard to the soil properties, the models fit in this study agreed partially with Carvalho et al. (2002), Johann et al. (2004), Souza et al. (2004b), Santos et al. (2006), where sometimes one, sometimes another model was observed.

The range of spatial dependence for FDM was $9.7 \mathrm{~m}$, so that the extreme values for the $\mathrm{BD}$ and MA ranged from $9.0 \mathrm{~m}$ (BD2) to $38.0 \mathrm{~m}$ (MA2c). These results were similar to those reported by Carvalho et al. (2002, 2003) and Grego \& Vieira (2005), varying from 3.9 to $23.7 \mathrm{~m}$ (TP) and 1.0 to $13.1 \mathrm{~m}(\mathrm{SD})$.

By cross-validation (Table 3), the simple krigings for \#TP1b provided the best semivariogram fitting, which could be observed by the highest correlation coefficient $(r=0.696)$ between observed and predicted values of this attribute, and by the linear coefficient (a) tending to zero and the angular coefficient (b) tending to one. The correlation coefficients of the other properties ranged from 0.338 to 0.535 , and the linear coefficients tended to 0.00 and the angular coefficients were between 0.765 and 1.002 , as similarly reported by Souza et al. (2001), Carvalho et al. (2002, 2003), and Santos et al. (2006).

With regard to the co-krigings (Table 3), the best fit was observed for the plant property STD $=\mathrm{f}$ (BD1), which had the highest spatial determination coefficient $\left(r^{2}=0.430\right)$, as well as the appreciable values of the coefficients a (1.140) and $b(0.543)$. The performance of the other properties was similar to STD, with $\mathrm{r}^{2}$ values between 0.381 and 0.424 , as well as values of a between $6.282 .10^{3}$ and $7.307 .10^{3}$, and $\mathrm{b}$ between 0.581 and 0.507 .

Thus, the principle of converging evidence showed that: a) MA1 and TP1b were inversely and significantly correlated with FDM, b) \# TP1b and TP3 showed very good simple semivariogram fittings (Table 2) and c) the semivariogram fitting between FDM and \# MI1 (Figure 4), showed high spatial dependence between the plant and soil properties.

\section{CONCLUSIONS}

1. The studied properties followed well-defined spatial patterns, ranging from 7.8 to $38.0 \mathrm{~m}$.

2. The correlations between FDM with MA1 and TP1b were negative. From the spatial viewpoint, there was an excellent positive correlation between the FDM and MI1 and there was no significant correlation of FDM with bulk density in any layer.

3. The linear correlation between forage dry matter and soil microporosity was low, although extremely significant. But from the spatial viewpoint, there was a high inverse correlation between these variables; with increasing microporosity, forage productivity decreased.

4. Of the soil physical properties studied, microporosity in the $0.00-0.10 \mathrm{~m}$ layer was the soil physical quality that correlated best with forage dry matter.

\section{LITERATURE CITED}

ARAÚJO, F.S.; SALVIANO, A.A.C.; LEITE, L.F.C.; SOUZA, Z.M. \& SOUSA, A.C.M. Physical quality of a Yellow Latossol under integrated crop-livestock system. R. Bras. Ci. Solo, 34:717-723, 2010.

ASSIS, R.L. \& LANÇAS, K.P. Efeito do tempo de adoção do sistema plantio direto na densidade do solo máxima e umidade ótima de compactação de um Nitossolo Vermelho distroférrico. R. Bras. Ci. Solo, 28:337-345, 2004.

BERGAMIN, A.C.; VITORINO, A.C.T.; LEMPP, B.; SOUZA, C.M.A. \& SOUZA, F.R. Anatomia radicular de milho em solo compactado. Pesq. Agropec. Bras., 45:299-305, 2010.

CARVALHO, M.P.; SORATTO, R.P. \& FREDDI, O.S. Variabilidade espacial de atributos físicos em um Latossolo Vermelho Distrófico sob preparo convencional em Selvíria, estado de Mato Grosso do Sul. Acta Sci., 24:1353-1361, 2002.

CARVALHO, M.P.; TAKEDA, E.Y. \& FREDDI, O.S. Variabilidade espacial de atributos de um solo sob videira em Vitória Brasil (SP). R. Bras. Ci. Solo, 27:95-703, 2003.

CAVALIERI, K.M.V.; TORMENA, C.A.; VIDIGAL FILHO, P.S.; GONÇALVES, A.C.A. \& COSTA, A.C.S. Efeitos de sistemas de preparo nas propriedades físicas de um Latossolo Vermelho distrófico. R. Bras. Ci. Solo, 30:137-147, 2006. 
DEBIASI, H.; LEVIEN, R.; TREIN, C.R.; CONTE, O. \& KAMIMURA, K.M. Produtividade de soja e milho após coberturas de inverno e descompactação mecânica do solo. Pesq. Agropec. Bras., 45:603-612, 2010.

DEXTER, A.R.; CZYZ, E.A. \& GAT, O.P. A method for prediction of soil penetration resistance. Soil Tillage Res., 93:412-419, 2007.

EMPRESA BRASILEIRA DE PESQUISA AGROPECUÁRIA EMBRAPA. Manual de métodos de análise do solo. 2.ed. Rio de Janeiro, 1997. 212p.

EMPRESA BRASILEIRA DE PESQUISA AGROPECUÁRIA EMBRAPA. Sistema brasileiro de classificação de solos. 2.ed. Rio de Janeiro, 2006. 306p.

FOLONI, J.S.S.; CALONEGO, J.C. \& LIMA S.L. Efeito da compactação do solo no desenvolvimento aéreo e radicular de cultivares de milho. Pesq. Agropec. Bras., 38:947-953, 2003.

FREDDI, O.S.; CARVALHO, M.P.; VERONESI JÚNIOR, V. \& CARVALHO, G.J. Produtividade do milho relacionada com a resistência mecânica à penetração do solo sob preparo convencional. Eng. Agríc., 26:113-121, 2006.

FREDDI, O.S.; FERRAUDO, A.S. \& CENTURION, J.F. Análise multivariada na compactação de um Latossolo Vermelho cultivado com milho. R. Bras. Ci. Solo, 32:953-961, 2008.

GREGO, C.R. \& VIEIRA, S.R. Variabilidade espacial de propriedades físicas do solo em uma parcela experimental. R. Bras. Ci. Solo, 29:169-177, 2005.

JOHANN, J.A.; URIBE-OPAZO, M.A.; SOUZA, E.G. \& ROCHA, J.V. Variabilidade espacial dos atributos físicos do solo e da produtividade em um Latossolo Bruno Distrófico da região de Cascavel, PR. R. Bras. Eng. Agríc. Amb., 8:212-219, 2004.

KUTÝLEKA, M.; JENDELEB, L. \& PANAYIOTOPOULOS, K.P. The influence of uniaxial compression upon pore size distribution in bi-modal soils. Soil Tillage Res.,86:27-37, 2006.

LIMA, C.L.R.; REINERT, D.J.; REICHERT, J.M. \& SUZUKI, L.E.A.S. Compressibilidade de um Argissolo sob plantio direto escarificado e compactado. Ci. Rural, 36:1765-1772, 2006.

MELO FILHO, J.F.; OLIVEIRA, A.S.; LOPES, L.C. \& VELLAME, L.M. Análise estatística exploratória e variabilidade da densidade do solo em um perfil de Latossolo Amarelo coeso dos tabuleiros costeiros da Bahia. Ci. Agrotec., 30:199-205, 2006.
MERCANTE, E.; URIBE-OPAZO, M.A. \& SOUZA, E.G. Variabilidade espacial e temporal da resistência mecânica do solo à penetração em áreas com e sem manejo químico localizado. R. Bras. Ci. Solo, 27:1149-1159, 2003.

PEREIRA, F.S.; ANDRIOLI, I.; BEUTLER, A.N.; ALMEIDA, C.X. \& PEREIRA, F.S. Physical quality of an Oxisol cultivated with maize submitted to cover crops in the precropping period. R. Bras. Ci. Solo, 34:211-218, 2010.

SANTOS, M.L.; CARVALHO, M.P.; RAPASSI, R.M.A.; MURAISHI, C.T.; MALLER, A. \& MATOS, F.A. Correlação linear e espacial entre produtividade de milho (Zea mays L.) e atributos físicos de um Latossolo Vermelho distroférrico sob plantio direto do Cerrado Brasileiro. Acta Sci., 28:313$321,2006$.

SECCO, D.; DAROS, C.O.; SECCO, J.K. \& FIORIN, J.E. Atributos físicos e produtividade de culturas em um Latossolo Vermelho argiloso sob diferentes sistemas de manejo. R. Bras. Ci. Solo, 29:407-414, 2005.

SILVA, A.J.N.; CABEDA, M.S.V. \& CARVALHO, F.G. Propriedades físico-hídricas em Latossolo do Cerrado sob diferentes sistemas de manejo. R. Bras. Eng. Agríc. Amb., 13:146-151, 2009.

SOUSA NETO, E.L.; ANDRIOLI, I.; BEUTLER, A.N. \& CENTURION, J.F. Atributos físicos do solo e produtividade de milho em resposta a culturas pré-safra. Pesq. Agropec. Bras., 43:255-260, 2008.

SOUZA, Z.M.; SILVA, M.L.S.; GUIMARÃES, G.L.; CAMPOS, D.T.S.; CARVALHO, M.P. \& PEREIRA, G.T. Variabilidade espacial de atributos físicos em um Latossolo Vermelho Distrófico sob semeadura direta em Selvíria (MS). R. Bras. Ci. Solo, 25:699-707, 2001.

SOUZA, Z.M.; MARQUES JÚNIOR, J. \& PEREIRA, G.T. Variabilidade espacial de atributos físicos do solo em diferentes formas do relevo sob cultivo de cana-de-açúcar. R. Bras. Ci. Solo, 28:937-944, 2004a.

SOUZA, Z.M.; MARQUES JÚNIOR, J.; PEREIRA, G.T. \& BENTO, M.J.C. Variabilidade espacial de atributos físicos de um Latossolo Vermelho sob cultivo de cana-de-açúcar. R. Bras. Eng. Agríc. Amb., 8:51-58, 2004b. 
